\title{
ANALISIS PELAKSANAAN KEGIATAN PRAMUKA DI SD NEGERI 004 SAMARINDA UTARA TAHUN 2019
}

\author{
Afdal, Heri Widodo \\ Universitas Widya Gama Mahakam Samarinda \\ afdlpalalloi@yahoo.com \\ widodo.wh91@gmail.com
}

\begin{abstract}
Abstrak
Peneliti ini bertujuan untuk mengetahui bagaimana pelaksanaan kegiatan pramuka di SD Negeri 004 Samarinda Utara Tahun 2019. Metode yang digunakan dalam penelitian ini adalah metode kualitatif, dan teknik yang digunakan adalah snowball sampling dan subjek penelitian ini meliputi kepala sekolah, dua pembina pramuka dan anggota pramuka, sedangkan objek penelitian adalah pelaksanan kegiatan pramuka di SDN 004 Samarinda Utara. Teknik yang digunakan dalam triangulasi ini adalah triangulasi sumber yatu menggunakan banyak sumber untuk satu data dengan membandingkan antara hasil wawancara dengan data yang ada pada dokumen observasi. Dilakukan konsultasi dengan kepala sekolah dan dua pembina pramuka yang akan melaksanakan kegiatan pramuka di lokasi penelitian. Keabsahan data penelitian ini didapatkan dari proses membandingkan hasil wawancara dengan observasi dan dokumentasi. Berdasarkan hasil analisis data penelitian, maka dimperoleh penemuan berikut: (1) sekolah sudah mempersiapkan program tersruktur sebelum melakukan kegiatan pramuka, mempersiapkan sarana prasarana, dan sekolah menyediakan dana dari Bantuan Operasional Sekolah (BOS). (2) dalam pelaksanaan kegiatan pramuka, pembina pramuka menyiapkan rencana kegiatan pramuka sesuai dengan buku Syaratsyarat Kecakapan Umum ( SKU) Pramuka.
\end{abstract}

Kata kunci: Pelaksanaan, Kegiatan Pramuka,

\section{PENDAHULUAN}

Pendidikan adalah usaha untuk mendapatkan pengetahuan, baik secara formal melalui sekolah maupun secara informal dari pendidikan di dalam rumah dan masyarakat (Elfachmi, 2016: 13). Sedangkan menurut Horn ( Elfachmi, 2016: 13) menjelaskan pendidikan adalah proses abadi dari penyesuaian lebih tinggi bagi makhluk yang telah berkembang secara fisik dan mental yang bebas dan sadar kepada Tuhan seperti termanifestasi dalam alam sekitar, intelektual, emosional dan kemauan dari manusia.

Sekolah merupakan suatu lembaga pendidikan yang bertanggung jawab memberikan berbagai pengetahuan dan keterampilan, serta mengembangkan berbagai nilai dan sikap, baik melalui pendidikan formal maupun non formal. Di sekolah pun terdapat proses belajar mengajar seperti kegiatan yang dilakukan di sekolah dengan waktu yang telah ditentukan dalam struktur program. Kegiatan ini dilakukan agar peserta didik dapat mencapai tujuan pada setiap mata pelajaran. Kegiatan yang dilakukan diluar jam belajar yaitu kegiatan pramuka.

Kegiatan ini bertujuan agar peserta didik dapat memperdalam dan menghayati apa yang dipelajari dalam kegiatan tersebut. Tujuan pendidikan nasional berdasarkan Undang-undang
No 2 Tahun 2003 tentang sistem pendidikan nasional adalah untuk berkembangnya potensi peserta didik agar menjadi manusia yang beriman dan bertakwa kepada Tuhan Yang Maha Esa, berakhlak mulia, sehat, berilmu, cakap, kreatif, mandiri dan menjadi warga negara yang demokratis serta bertanggung jawab.

Undang-Undang ini menegaskan Pancasila merupakan asas gerakan pramuka dan gerakan pramuka berfungsi sebagai wadah untuk mencapai tujuan pramuka melalui kegiatan. Menurut Undang-undang Republik Indonesia No 12 Tahun 2010 tentang kepramukaan yaitu pendidikan dan pelatihan, pengembangan, pengabdian masyarakat dan orang tua, serta permainan yang berorientasi pada pendidikan.

Selanjutnya, tujuan gerakan pramuka adalah membentuk setiap pramuka agar memiliki kepribadian yang beriman, bertakwa, berakhlak mulia, berjiwa patriotik, taat hukum, disiplin, menjunjung tinggi nilai-nilai luhur bangsa dan memiliki kecakapan hidup sebagai kader bangsa dalam menjaga dan membangun Negara Kesatuan Republik Indonesia, mengamalkan Pancasila, serta melestarikan lingkungan hidup.

Pengembangan potensi peserta didik yang dimaksud dalam tujuan nasional tersebut dapat diwujudkan melalui kegitan pramuka. Kegiatan 
pramuka mempunyai peran penting dalam pelajaran sekolah. Pramuka merupakan kegiatan yang dilakukan diluar jam sekolah, kegiatan yang dilakukan diluar jam sekolah memberi banyak pengaruh terhadap pribadi anak. Kepribadian anak yang baik sangatlah penting dalam kegiatan pembelajaran di sekolah.

Kegiatan pramuka ini bertujuan agar siswa dapat lebih meningkatkan kemampuan tentang apa yang telah dan akan dipelajarinya, serta menyalurkan bakat minat dan membantu mewujudkan pembentukan watak pada anak. SD Negeri 004 Samarinda Utara telah melaksanakan kegiatan pramuka, baik wajib maupun pilihan. Pelaksanaan kegiatan pramuka tersebut pelaksanaannya masih terdapat berbagai masalah, contohnya kurangnya perlengkapan pramuka, padahal kegiatan pramuka ini adalah kegiatan wajib bagi siswa.

Menurut Peraturan Menteri Pendidikan Dan Kebudayaan Republik Indonesia Nomor 63 Tahun 2014 pasal 8 tentang kurikulum pendidikan Kepramukaan, menjelaskan kegiatan pramuka merupakan kegiatan wajib yang merunjuk pada pedoman penyelenggaraan pendidikan kepramukaan sebagai kegiatan wajib dan prosedur operasi standar (POS).

Menurut Powell, mengemukakan bahwa kepramukaan yaitu keperamukaan itu bukanlah suatu ilmu yang harus dipelajari dengan tekun, bukan pula merupakan kumpulan ajaran-ajaran dan naskah-naskah dari suatu buku melainkan suatu kegiatan yang dilakukan diluar jam atau di alam terbuka (Boyman, 2013: 03).

Di SD Negeri 004 Samarinda Utara dalam kegiatan pramukanya masih terdapat berbagai masalah, yang salah satunya adalah kurangnya peralatan seperti alat peraga. Hal tersebut memberikan gambaran tentang kegiatan pramuka yang belum tertanam secara maksimal, contohnya ketika diberi tugas kelompok oleh pembina pramuka, hanya sebagian siswa saja yang benarbenar mengerjakan tugasnya, sedangkan siswa yang lain hanya bermain-main dan tidak mengerjakan tugasnya dengan baik.

\section{KAJIAN PUSTAKA}

\subsection{Pengertian Pramuka}

Pramuka adalah kepanjangan dari Praja Muda Karana yang memiliki arti kaum muda yang suka berkarya. Nasrudin (2018: 01) menjelaskan pramuka adalah setiap pemuda yang aktif dalam kegiatan kepramukaan dan di didik dengan berbagai keterampilan, disiplin, kepercayaan pada diri sendiri, saling menolong dan lain sebagainya.

Menurut Undang-undang Republik Indonesia Nomor 12 Tahun 2010 menyatakan bahwah Pendidikan Kepramukaan adalah proses pembentukan kepribadian, kecakapan hidup dan akhlak mulia pramuka melalui penghayatan dan pengamalan nilai-nilai kepramukaan.

Jayanti (2016: 21) menjelaskan pramuka adalah anggota gerakan pramuka yang terdiri dari anggota muda yaitu peserta didik Siaga, Penggalang, Penegak dan Pendega. Tingakatan dalam kepramukaan telah ditentukan oleh umur anggotanya seperti, kelompok umur 7-10 tahun disebut degan pramuka siaga. Kelompok umur 1115 tahun disebut dengan pramuka penggalang. Kelompok umur 16-20 tahun disebut dengan pramuka penegak. Kelompok umur 21-25 tahun disebut dengan pramuka pendega.

Kegiatan kepramukaan juga memiliki kelompok khusus, yaitu kelompok yang ditunjukan untuk orang yang memiliki kedudukan dalam kepramukaan. Misalnya pramuka pembina adalah sebutan untuk orang dewasa yang memimpin pramuka. dan pramuka Andalan adalah anggota pramuka yang mengambil bagian dalam keanggotaan Kwartir dalam pramuka. Contoh lainnya adalah pelatih, pamong Saka, staff Kwartir dan majelis pembimbing.

Nasrudin (2018: 1) menjelaskan kepramukaan adalah segala bentuk kegiatan dan lain sebagainya yang berhubungan dengan pramuka. Kegiatan yang dimaksud adalah kegiatan-kegiatan yang menarik dan mengandung nilai-nilai pendidikan.

Adapun menurut Undang-undang Republik Indonesia Nomor 12 Tahun 2010 pasal 1 tentang gerakan pramuka yang menjadi dasar pokok penyelengaraan pendidikan kepramukaan di indonesia. Beberapa istilah didenifisikan sebagai berikut: (1) Pramuka adalah warga negara indonesia yang aktif dalam pendidikan kepramukaan dan mengamalkan Satya pramuka dan Darma pramuka. (2) Gerakan Pramuka adalah organisasi yang dibentuk oleh pramuka untuk menyelenggarakan pendidikan kepramukaan. (3) Kepramukaan adalah segala aspek yang berkaitan dengan pramuka. (4) Pendidikan Pramuka adalah proses pembentukan kepribadian, kecakapan hidup, dan akhlak mulia pramuka melalui penghayatan dan pengamalan nilai-nilai kepramukan. 
Kwartir Nasional Gerakan Pramuka 200 9 (Utomo, 2015: 14) menyebutkan bahwa kepramukaan adalah proses pendidikan di luar lingkungan sekolah dan di luar lingkungan keluarga dalam bentuk kegiatan menarik, menyenangkan, sehat, teratur, terarah, praktis yang dilakukan dialam terbuka dengan prinsip dasar kepramukaan, yang sasaran akhirnya pembentukan watak, akhlak dan budi pekerti luhur.

Berdasarkan beberapa penjelasan di atas dapat disimpulkan kepramukaan adalah pendidikan di luar lingkungan sekolah dan diluar lingkungan keluarga dalam bentuk kegiatan menarik dan menyenagkan bagi anak muda dibawah tanggung jawab anggota dewasa, sehat, teratur, terarah dan praktis yang dilakukan di alam terbuka dengan prinsip dasar kepramukaan dan metode kepramukaan yag sasaran akhirnya adalah pembentukan watak, sedangkan pramuka merupakan anggota dari gerakan pramuka yang melaksanakan kegiatan kepramukaan.

\subsection{Prinsip Dasar dan Metode Pramuka}

a. Prinsip Dasar Kepramukaan

Nasrudin (2018: 74) menjelaskan prinsip dasar kepramukaan sebagai norma hidup seorang anggota gerakan pramuka, ditanamkan dan ditumbuhkembangkan melalui proses penghayatan oleh dan untuk diri pribadinya dengan dibantu oleh pembina, sehingga pelaksanaan dan pengalamannya dilakukan dengan penuh kesadaran, kemandirian, kepedulian, tanggung jawab serta keterikatan moral, baik sebagai pribadi maupun anggota masyarakat.

Prinsip dasar kepramukaan ada empat yaitu (1) keimanan dan ketakwaan kepada Tuhan Yang Maha Esa; (2) kepedulian terhadap bangsa dan tanah air, sesama hidup dan alam seisinya; (3) kepedulian terhadap diri pribadinya; (4) ketaatan kepada kode kehormatan pramuka (Boyman,2013: 87).

Kwartir Nasional Gerakan Pramuka (2011: 29) menjelaskan fungsi prinsip dasar kepramukaan ada lima yaitu (1) norma hidup anggota gerakan pramuka; (2) landasan kode etik gerakan pramuka; (3) landasan sistem nilai gerakan pramuka; (4) pedoman dan arah pembinaan kaum muda anggota gerakan pramuka; (5) landasan gerakan dan kegiatan pramuka mencapai sasaran dan tujuannya. Dengan itu prinsip dasar kepramukaan hendaknya dapat ditanamkan secara mendalam, karena semua prilaku anggota gerakan pramuka akan dijiwai olehnya. Selain itu prinsip dasar kepramukaan merupakan ciri khas yang membedakan kepramukaan dari pendidikan lainnya.

b. Metode Kepramukaan

Kwartir Nasional Gerakan Pramuka (2011: 31) menjelaskan bahwa metode kepramukaan adalah cara memberikan pendidikan kepada peserta didik melalui kegiatan menarik, menyenangkan dan menantang, yang disesuaikan kondisi, situasi dan kegiatan peserta didik.

Metode kepramukaan merupakan cara belajar yang progesif melalui: (1) pengalaman kode kehormatan pramuka; (2) belajar sambil melakukan; (3) sistem beregu; (4) kegiatan yang menarik dan menantang di alam terbuka yang mengandung pendidikan yang sesuai dengan perkembangan rohani dan jasmani anggota muda; (5) kegiatan dialam terbuka; (6) kemitraan dengan anggota dewasa dalam setiap kegiatan; (7) sistem tanda kecakapan; (8) sistem satuan terpisah untuk putera dan puteri; (8) kiasan dasar. Pelaksanaan metode kepramukaan pada hakekatnya tidak dapat dilepas dari prinsip dasar kepramukaan. Metode kepramukaan sebagai suatu sistem terdiri atas unsur-unsur pengalaman kode kehormatan, belajar sambil melakukan, sistem berkelompok, kegiatan yang menantang yang mengandung pendidikan, kegiatan di alam terbuka, sistem tanda percakapan, sistem satuan terpisah untuk putera dan puteri dan sistem among.

\subsection{Macam-macam Kegiatan Pramuka}

Kegiatan pramuka diharapkan peserta didik yang mengikuti mendapat berbagai keterampilan maupun pengetahuan yang dapat membentuk watak pada peserta didik. Keterampilan kepramukaan merupakan materi yang diperoleh seorang pramuka dari kegiatan yang diikutinya, Kwartir Nasional (2011: 133).

Keterampilan ini menjadi bekal pengetahuan praktis yang siap dimanfaatkan sewaktu-waktu. Penguasaan pengetahuan keterampilan ini disesuaikan dengan golongan usia pramuka, lamanya seorang anggota pramuka mengikuti kegiatan pramuka, serta kualitas pembina pramuka dalam memberikan materi tersebut.

Menurut Permendikbud No 63 Tahun 2014 tentang kepramukaan, menyebutkan berbagai macam-macam kegiatan keterampilan dalam 
kepramukaan yang dapat membentuk karakter peserta didik, termaksuk meningkatkan pengetahuan dan keterampilan sebagai berikut:

a. Keterampilan Tali Temali

Keterampilan Tali Temali digunakan dalam berbagai keperluan diantaranya membuat tandu, memasang tenda, membuat tiang jemuran dan tiang bendera. Setiap anggota gerakan pramuka diharapkan mampu dan dapat membuat dan menggunakan tali-temali dengan baik. Tujuan dalam membuat simpul dan ikatan diharapkan anggota pramuka dapat membentuk karakter ketelitian, kesabaran, kerjasama dan tanggung jawab. Membuat tanda diharapkan dapat membentuk karakter ketelitian, kesabaran, kerjasama dan tanggung jawab, (Utomo, 2015: 17).

b. Keterampilan Pertolongan Pertama Gawat Garurat(PPGD)

Keterampilan Pertolongan Pertama Gawat Darurat (PPGD) merupakan kegiatan untuk memberikan pertolongan pertama pada korban kecelakaan atau orang sakit. Yang perlu diperhatikan dalam hal ini adalah bahwa tindakan ini hanya tindakan pertolongan sementara. Langkah berikutnya tetap harus segera dibawa ke puskesmas atau rumah sakit terdekat. Tujuan dalam mencari dan memberi obat diharapkan dapat membentuk karakter ketelitian, kesabaran, kerjasama, tanggung jawab dan peduli sosial. Membalut luka, menggunakan bidai dan mitela diharapkan dapat membentuk karakter ketelitian, kesabaran, kerjasama, tanggung jawab dan peduli sosial, (Utomo, 2015: 18).

c. Ketangkasan Pionering

Ada beberapa kegiatan keterampilan dan pengetahuan yang sekiranya dapat membantu membuat kegiatan kepramukaan tetap menarik dan menantang minat peserta didik untuk tetap menjadi anggota gerakan pramuka. Kegiatan ketangkasan pionering merupakan kegiatan yang sudah biasa dalam kegiatan kepramukaan. Kegiatan itu meliputi membuat gapura, menara pandang, membuat tiang bendera, membuat jembatan tali goyang, meniti dengan satu atau dua tali.

Tujuan dalam kegiatan membuat gapura, menara pandang dan membuat tiang bendera diharapkan dapat membentuk karakter ketelitian, percaya diri, ketekunan dan kerjasama. Dalam kegiatan membuat jembatan tali goyang dan meniti dengan satu atau dua tali diharapkan dapat membentuk karakter keberanian, ketelitian, percaya diri, ketekunan dan kesabaran, (Utomo, 2015: 18).

d. Keterampilan Morse dan Semaphore

Kedua keterampilan ini sebenarnya merupakan bahasa sandi dalam kepramukaan. Perbedaan keduanya adalah terletak pada penggunaan media. Morse menggunakan media peluit, senter, bendera dan pijatan. Semaphore menggunakan media bendera kecil berukuran $45 \mathrm{~cm} \times 45 \mathrm{~cm}$. Keterampilan ini perlu dimiliki oleh setiap anggota gerakan pramuka agar dalam kondisi darurat mereka tetap dapat menyampaikan pesan. Morse dan Semaphore diharapkan dapat membentuk karakter kecermatan, ketelitian, tanggung jawab dan kesabaran, (Utomo, 2015: 19).

e. Keterampilan Membaca Sandi Pramuka

Keterampilan ini sangat diperlukan dalam kegiatan penyampaian pesan rahasia dengan menggunakan kunci yang telah disepakati. Seorang pramuka harus dapat dipercaya untuk dapat melakukan segala hal termasuk penyampaian dan penerimaan pesan-pesan rahasia. Dalam menyampaikan pesan rahasia ini diperlukan kode-kode tertentu yang dalam kepramukaan disebut sandi.

Sandi dalam pramuka antara lain sandi akar, sandi kotak biasa, sandi kotak berganda, sandi merah putih, sandi paku dan sandi angka. Dalam sandi akar, sandi kotak biasa, sandi kotak berganda, sandi merah putih, sandi paku dan sandi angka diharapkan dapat membentuk karakter kreatif, ketelitian, kerjasama dan tanggung jawab. Manfaat dari sandi akar, sandi kotak biasa, sandi kotak berganda, sandi merah putih, sandi paku dan sandi angka dapat membentuk karakter kreatif, ketelitian, kerjasama dan tanggung jawab, (Utomo, 2015: 20).

f. Penjelajahan dengan Tanda Jejak

Kegiatan ini merupakan salah satu bentuk latihan berpetualang. Anggota gerakan pramuka harus terbiasa dengan alam bebas. Di alam bebas tidak terdapat rambu-rambu secara jelas sebagaimana di jalan raya. Oleh karena itu, seorang anggota gerakan pramuka harus dapat memanfaatkan fasilitas alam sebagai petunjuk arah dan atau tanda bahaya kepada teman kelompoknya. Manfaat Penjelajahan dengan memasang dan membaca tanda jejak diharapkan dapat membentuk karakter religius, toleransi, cinta tanah air, peduli lingkungan, kerja sama dan tanggung jawab, (Utomo, 2015: 20).

g. Kegiatan Pengembaraan 
Kegiatan pengembaraan ini bukan sekedar jalan-jalan di alam bebas atau rekreasi bersama melainkan melakukan perjalanan dengan berbagai rintangan yang perlu diperhitungkan agar tujuan kita dapat dicapai. Hal ini dengan sendirinya juga mendidik generasi muda bahwa untuk dapat mencapai cita-cita itu banyak rintangan dan sangat memerlukan perjuangan yang kuat.

Oleh karena itu, pendidikan di alam bebas dengan berbagai rintangan merupakan pendidikan yang menantang dan menyenangkan. Manfaat dari kegiatan pengembaraan ini agar dapat membentuk karakter mandiri, peduli lingkungan, tangguh, tanggung jawab, kepemimpinan, kerja sama, peduli sosial, ketelitian dan religius, (Utomo, 2015:21).

h. Keterampilan Baris-Berbaris (KBB)

Di lingkungan gerakan pramuka, peraturan baris-berbaris disebut keterampilan barisberbaris. Kegiatan ini merupakan keterampilan untuk melaksanakan perintah atau instruksi yang berkaitan dengan gerakan-gerakan fisik. Keterampilan Baris-berbaris ini dilakukan untuk melatih kedisiplinan, kekompakan, keserasian dan seni dalam berbaris. Tujuan dari keterampilan baris-berbaris ini diharapkan dapat membentuk karakter kedisiplinan, kreatif, kerja sama dan tanggung jawab, (Utomo, 2015: 21).

i. Keterampilan Menentukan Arah

Keterampilan ini merupakan suatu upaya bagi anggota gerakan pramuka untuk mengetahui arah. Dalam penentuan arah ini dapat digunakan kompas dan benda yang ada di alam sekitar, misalnya: kompas sederhana (silet, magnet, dan air) bintang, pohon dan matahari. Hal ini sangat penting apabila anggota gerakan pramuka itu tersesat di alam bebas ketika melakukan pengembaraan. Tujuan keterampilan menentukan arah ini diharapkan dapat membentuk karakter kreatif, kerja keras, rasa ingin tahu dan kerja sama, (Utomo, 2015: 22).

\subsection{Fungsi Kegiatan Pramuka}

Menurut Lord Baden Powell (Boyman, 2013: 3) tentang kepramukaan adalah suatu permainan yang menyenangkan di alam terbuka, dimana tempat orang dewasa dan anak-anak pergi bersama-sama, mengadakan pengembaraan bagaikan kakak beradik, membina kesehatan dan kebahagian, keterampilan dan kesediaan untuk memberikan pertolongan bagi yang membutuhkan.
Permendikbud No 63 Tahun 2014 Tentang Kepramukaan, kepramukaan mempunyai fungsi sebagai berikut:

a. Kegiatan menarik bagi anak atau pemuda.

Kegiatan menarik di sini dimaksudkan kegiatan yang menyenangkan dan mengandung pendidikan. Karena itu permainan harus mempunyai tujuan dan aturan permainan, jadi bukan kegiatan yang hanya bersifat hiburan saja.

b. Pengabdian bagi orang dewasa.

Bagi orang dewasa kepramukaan bukan lagi permainan, tetapi suatu tugas yang memerlukan keikhlasan, kerelaan dan pengabdian.Orang dewasa mempunyai kewajiban untuk secara sukarela membaktikan dirinya demi suksesnya pencapaian tujuan organisasi.

c. Alat bagi masyarakat dan organisasi.

Kepramukaan merupakan alat bagi masyarakat untuk memenuhi kebutuhan masyarakat setempat dan juga alat bagi organisasi untuk mencapai tujuan organisasinya.

\subsection{Tujuan Kegiatan Pramuka}

Permendikbud Nomor 63 Tahun 2014

Tentang Kepramukaan, dijelaskan Gerakan Pramuka bertujuan untuk membentuk setiap pramuka:

1. Memiliki kepribadian yang beriman, bertakwa, berakhlak mulia, berjiwa patriotik, taat hukum, disiplin, menjunjung tinggi nilainilai luhur bangsa, berkecakapan hidup, sehat jasmani dan rohani.

2. Menjadi warga negara yang berjiwa Pancasila, setia dan patuh kepada Negara Kesatuan Republik Indonesia serta menjadi anggota masyarakat yang baik dan berguna, yang dapat membangun dirinya sendiri secara mandiri serta bersama-sama bertanggungjawab atas pembangunan bangsa dan negara, memiliki kepedulian terhadap sesama hidup dan alam lingkungan.

Menteri Pendidikan dan Kebudayaan Republik Indonesia Nomor 81A Tahun 2013 Tentang Implementasi Kurikulum 2013, dijelaskan bahwa tujuan kegiatan ekstrakurikuler Pramuka pada satuan pendidikan adalah untuk: (1) Meningkatkan kemampuan kognitif, afektif, dan psikomotor peserta didik; (2) Mengembangkan bakat dan minat peserta didik dalam upaya pembinaan pribadi menuju pembinaan manusia seutuhnya. 


\subsection{Tingkatan Pramuka di SD}

Pramuka adalah organisasi pendidikan nonformal yang menyelenggarakan pendidikan panduan. Di Indonesia, gerakan pramuka cukup aktif diajarkan di tingkat SD, SMP, dan SMA. tingkatan dalam kepramukaan yang telah di tentukan oleh umur anggotanya dibagi menjadi 4 kelompok yaitu:

a. Kelompok pramuka siaga

Siaga adalah sebutan bagi anggota pramuka yang berumur antara 7-10 tahun. Disebut pramuka siaga karena sesuai dengan kiasan dasar masa perjuangan bangsa Indonesia, yaitu ketika rakyat indonesia menyiagakan dirirnya untuk mencapai kemerdekaan dengan berdirinya Boedi Oetomo pada tahun 1908 sebagai tongkak awal perjuangan bangsa indonesia, (Nasruddin, 2018: 80).

Berdasarkan pencapaian syarat-syarat kecakapan umum pramuka siaga dapat digolongkan dalam tiga tingkatan, yaitu: 1) siaga mula, 2) siaga bantu, 3) siaga tata.

b. Kelompok pramuka penggalang

Penggalang adalah golongan setelah pramuka siaga. Anggita pramuka penggalang berusia antara 11-15 tahun. Disebut pramuka penggalang karena sesuai dengan kiasan pada masa persatuan dan kesatuan bangsa indonesia pada masa perjuangan,yaitu ketika rakyat "menggalang" dan mempersatukan dirinya untuk mencapai kemerdekaan dengan adanya peristiwa bersejarah yaitu kongres para pemuda indonesia yang kemudian menghasilkan sumpah pemuda pada 28 oktober 1928, jayanti (2018: 94). Berdasarkan pencapaian syarat-syarat kecakapan umum pramuka penggalang dapat digolongkan dalam beberapa tingkatan, yaitu: 1) penggalang ramu, 2) penggalang Rakit, 3) penggalang Terap.

c. Kelompok pramuka penegak

Penegak adalah golongan pramuka setelah penggalang. Penegak adalah anggota gerakan pramuka yang sudah memasuki jenjang umur 16-20 tahun (Jayanti: 33). Ada dua tingkatan dalam penegak, yaitu: 1) penegak bantara dan 2) penegak laksana.

d. Kelompok pramuka pendega

Pendega adalah golongan pramuka setelah penegak. Anggota yang termasuk dalam golongan ini adalah yang berusia 2125 tahun. Pramuka pendega memiliki jenis kegiatan yang sama dan dilakukan bersamasama dengan pramuka penegak, (Jayanti: 39 ). Pembinaan pramuka pendega dilakukan mulai dari tingkat gugusdepan dalam satuan yang disebut Rencana, dan di tingkat kwartir dapat mengikuti satuan karya dan dewan kerja.

Ada juga kelompok khusus, yaitu kelompok yang ditunjukan untuk orang yang memiliki kedudukan dalam kepramukaan. Misalnya pramuka pembina, adalah sebutan untuk orang dewasa yang memimpin pramuka. Dan pramuka andalan, adalah anggota pramuka yang mengambil bagian dalam keanggotaan kwartir dalam pramuka. Contoh lainya adalah pelatih, pamong saka, staff kwartir dan majelis pembimbing (Jayanti: 21).

\section{METODOLOGI PENELITIAN}

Metode penelitian kualitatif dinamakan sebagai metode baru, karena popularitasnya belum lama, dinamakan metode postpositivistik karena berlandasan pada filsafat postpositivisme. Metode ini disebut juga sebagai metode artistik, karena proses penelitian lebih bersifat seni (kurang terpola), dan disebut sebagai metode wawancarakarena data hasil penelitian lebih berkenaan dengan interprestasi terhadap data yang ditemukan dilapangan.

Penelitian ini dilaksanakan di SD Negeri 004 Samarinda Utara. Adapun waktu penelitian ini dilaksanakan pada akhir bulan September sampai akhir bulan November 2019.

\subsection{Teknik Pengumpulan Data}

\subsubsection{Observasi}

Proses pengumpulan data penelitian ini menggunakan teknik obsevasi partisipatif dan observasi terus terang atau samar. Observasi partisipatif yaitu sebuah teknik pengumpulan data yang mengharuskan peneliti melibatkan diri dalam kehidupan dari masyarakat yang akan diteliti untuk dapat melihat dan memahami gejalagejala yang ada.

Sedangkan observasi terus terang atau samar yaitu peneliti dalam pengumpulan data menyatakan terus terang kepada subjek penelitian sebagai sumber data, bahwa dia sebagai peneliti sedang melakukan penelitian.

3.4.2 Wawancara/interview

Dalam wawancara ini peneliti memilih bentuk wawancara secara terstruktur, yaitu teknik 
mengumpulkan data, bila peneliti atau pengumpulan data telah mengetahui dengan pasti tentang informasi apa yang akan diperoleh. Oleh karena itu dalam melakukan wawancara, pengumpulan data telah menyiapkan instrumen penelitian berupa pertanyaan-pertanyaan tertulis yang alternatif jawabannya pun telah disiapkan.

Dengan wawancara ini setiap responden diberi pertanyaan yang sama dan pengumpul data mencatatnya. Dengan wawancara terstruktur ini pula, pengumpul data dapat menggunakan beberapa pewawancara sebagai pengumpul data (Sugiyono, 2018: 194-195).

\subsubsection{Dokumentasi}

Proses pengumpulan data penelitian ini menggunakan teknik dok umentasi. Menurut Bungin (2008: 121) teknik dokumentasi adalah salah satu metode yang digunakan dalam penelitian sosial untuk menelusuri data historis. Adapun pendapat menurut Guba \&linconln (2005) menyatakan bahwa dokumentasi adalah tingkat kredibilitas suatu hasil penelitian kualitatif sedikit banyaknya ditentukan pula oleh penggunaan dan pemanfaatan dokumen yang yang ada (Gunawan,2015:178).

Berdasarkan dari berbagai pendapat diatas, dapat disimpulkan bahwa dokumen merupakan sumber data yang digunakan untuk melengkapi penelitian, baik berupa sumber tertulis, film, gambar (foto), dan karya-karya monumental, yang semuanya itu memberikan informasi bagi proses penelitian.

\section{HASIL PENELITIAN DAN PEMBAHASAN Hasil Penelitian Kesiapan Kepala sekolah dan Pembina Pramuka}

Sebelum pelaksanaan kegiatan pramuka di SD Negeri 004 Samarinda Utara, pihak sekolah terlebih dahulu menyiapkan program terstruksturkegiatan pramuka untuk setiap satu semester atau setiap tahunnya. Hal tersebut sesuai dengan hasil wawancara kepala sekolah SD Negeri 004 Samarinda Utara menyatakan bahwa "setiap semester atau setiap tahunnya ada program terstrukstur dalam kegiatan pramuka tersebut". Hasil wawancara tersebut menunjukkan bahwa setiap semester pihak sekolah telah merencanakan kegiatan pramuka selama satu semester kedepan. Hal ini bertujuan agar penyampaian materi dapat diberikan secara sistematis dan bermanfaat bagi siswa yang mengikutinya.
Menurut pembina pramuka "Sekolah juga menyiapkan rencana kegiatan pramuka sesuai dengan panduan buku Syarat-Syarat Kecakapan Umum (SKU) pramuka". Hal ini juga diperkuat dengan pernyataan dari kepala sekolah SD Negeri 004 Samarinda Utara bahwa :

"Progam kegiatan pramuka selama satu semester meliputi pelatihan rutin setiap satu minggunya sekali yang dilaksanakan setiap hari Sabtu pukul 15.00-17.00, kemah setiap dua tahun sekali, jelajah, dan persami, rencana kegiatan tersebut disusun melalui program dan sesuai dengan panduan buku SKU pramuka" (Hasil wawancara pada tanggal 10 November 2019).

Berdasarkan hasil wawancara di atas dapat diketahui bahwa persiapanyang dilakukan sekolah dalam menunjang pelaksanaan kegiatan pramuka adalah menyiapkan rencana kegiatan rutin mingguan dan tahunan melalui program kegiatan pramuka yang dilaksanakan di SD Negeri 023 Samarinda Utara seperti latihan rutin setiap minggunya, kemah, jelajah, dan persami.

Kegiatan pramuka juga disesuaikan dengan panduan buku SKU pramuka. Pelaksanan kegiatan pramuka tersebut diawasi oleh Kepala Sekolah juga dan dikelola oleh pembina pramuka, berharap pelaksanaan kegiatan Pramuka dapat sesuai rencana kegiatan.Untuk latihan rutin, pelaksanaan kegiatan pramuka dilakukan di halaman sekolah.

Mengenai pelaksanaan pramuka di SD Negeri 004 Samarida Utara secara keseluruhan berjalan lancar hanya dalam pelaksanaannya masih belum sesuai dengan rencana progam sekolah dan sering terjadi keterlambatan dalam pelatihan rutin di setiap mingguannya. Dari hasil observasi yang dilakukan peneliti menunjukkan bahwa dalam pelaksanaan latihan rutin mingguan pembina tidak mengacu pada progam yang sudah disusun oleh pihak sekolah, selain itu pelaksanaan kegiatan sering terlambat sehingga pelaksanaan kegiatan pramuka tidak sesuai jadwal.

Keterlambatan pelaksanaan kegiatan tersebut mengurangi minat siswa tehadap kegiatan Pramuka tersebut.Hal ini nampak pada observasi yang dilakukan peneliti selama latihan rutin berlangsung. Sebelum kegiatan dimulai banyak siswa yang telah datang, hampir seluruh siswa kelas IV dan kelas V mengikuti kegiatan tersebut. Namun dengan demikian, pelaksanaan terlambat tidak sesuai dengan jadwal yang telah ditentukan.

Kegiatan Pramuka memiliki agenda latihan rutin tiap minggu yaitu setiap hari Sabtu pukul 15.00-17.00 dan dilaksanakan di halaman SD 
Negeri 004 Samarinda Utara. Setiap kali latihan diadakan absensi siswa, diantaranya absensi kelas dan perregu.Selain kegiatan latihan rutin mingguan, SD Negeri 004 Samarinda Utara juga memiliki agenda tahunan yang dilaksanakan di akhir semesternya.Pembina Pramuka SD Negeri 004 Samarinda Utara menjelaskan bahwa selain kegiatan latihan rutin mingguan, ada kegiatan khusus pada akhir semester atau akhir tahun dalam pelaksanaan Pramuka yang biasanya dilaksanakan di halaman sekolah.

Pelaksanaan kegiatan pramuka di SD Negeri 004 Samarinda Utara berjalan sesuai dengan metode dalam kegiatan Pramuka. Hal ini nampak dari kegiatan-kegiatan yang dilaksanakan. Dalam kegiatan latihan rutin yang dilaksanakan setiap minggu sekali diikuti oleh hampir seluruh siswa kelas IV dan V SD Negeri 004 Samarinda Utara. Dalam latihan rutin mingguan ini pembina pramuka sudah menggunakan Metode Kepramukaan. Dalam kegiatan pembelajaran siswa cukup antusias dengan dibentuknya regu kemudian diberi tugas secara mandiri.

Hasil observasi yang dilaksanakan peneliti selama latihan rutin mingguan berlangsung sejak September sampai November 2019 dapat diketahui bahwa pelaksanaan kegiatan Pramuka di SD Negeri 004 Samarinda Utara belum sesuai dengan program yang telah disusun pihak sekolah. Akan tetapi pembina maupun pembantu pembina pramuka SD Negeri 004 Samarinda Utara menggunakan Metode Kepramukaan dalam mengajar yang sesuai Metode Kepramukaan.

Hal ini nampak dari cara Pembina pramuka memberikan tugas kepada siswa untuk secara beregu, kegiatan dilakukan di alam terbuka yaitu di halaman sekolah, sistem satuan terpisah untuk putra dan untuk putri, ini menunjukan metode pengajaran menggunakan Metode Kepramukaan. Hal tersebut juga dibenarkan oleh siswa yang mengikuti, sebagai berikut: "Siswa dalam kegiatan selalu berkelompok atau beregu dalam setiap latihan."'(Hasil wawancara pada 20 November 2019).

Kemudian sistem penilaian dalam kegiatan Pramuka di SD Negeri 004 Samarinda Utara dengan cara penyampaian materi terlebih dahulu baru mengambil penilaian dari kegiatan yang sudah dilaksanakan atau lakukan disetiap akhir semesternya. Pembina pramuka mengambil penilaian siswa dengan cara memberikan latihanlatihan yang bisa berupa soal pertanyaan maupun latihan praktek yang dilangsungkan oleh siswa secara beregu. Menurut pembina pramuka ada beberapa aspek yang dinilai dalam Pramuka yaitu hasil penilaian diperoleh dari pemahaman siswa terhadap materi yang disampaikan dan dari penilaian terhadap sikap siswa selama mengikuti kegiatan (hasil wawancara pada 15 November 2019).

Pelaksanaan kegiatan Pramuka memiliki banyak pengaruh positifbagi siswa khususnya di SD Negeri 004 Samarinda Utara. Kepala Sekolah SD Negeri 004 Samarinda Utara mengungkapkan bahwa manfaat dan tujuan sekolah mengadakan kegiatan Pramuka adalah agar siswa mempunyai karakter dan watak yang baik. Beliau juga mengungkapkan bahwa setiap siswa mendapatkan banyak manfaat dalam mengikuti kegiatan Pramuka, diantaranya memiliki karakter dan watak yang baik seperti kedisiplinan, kemandirian, terampil, dan pengembangan diri siswa. (hasil wawancara pada 15 November 2019).

Selain bermanfaat dalam pembentukan karakter anak, kegiatan Pramuka juga bermanfaat bagi aktifitas siswa dalam pembelajaran dikelas.Kepala Sekolah juga menambahkan bahwa kegiatan pramuka ini sangat mendukung siswa dalam pembelajaran di kelas, karena kegiatan Pramuka adalah kegiatan yang dapat mempengaruhi sikap siswa di kelas. (Hasil wawancara pada 15 November 2019). Hal ini dibenarkan pula oleh pembina pramuka yang mengungkapkan sebagai berikut:“ kegiatan pramuka sangat mendukung siswa di kelas, karena memberi dampak pada sikap siswa di kelas dari tingkat kedisiplinannya" (hasil wawancara pada 15 November 2019). "

Hasil wawancara dan hasil observasi diatas menunjukan bahwa kegiatan Pramuka ini memberikan dampak positif bagi perkembangan watak dan kepribadian anak secara umum yaitu akan terbentuk kemandirian dan kedisiplinan anak. Dalam pelaksanaan kegiatan Pramuka tersebut pembina pramuka belum mengacu pada progam yang dibuat sekolah. Pembina pramuka tidak nampak melakukan penilain terhadap siswa baik secara individu maupun regu. Akan tetapi pelaksanaan latihan rutin di setiap minggu kegiatan Pramuka dapat dikatakan berjalan lancar dan siswa tergolong antusias dalam mengikuti kegiatan Pramuka, meskipun pelaksanaan sedikit terlambat sesuai jadwal yang ditentukan dan masih ada beberapa siswa yang terlambat datang 
atau tidak dapat mengikuti latihan karena berbagai hal.

\section{Faktor Pendukung Kegiatan Pramuka}

Faktor tersebut bisa berasal dari pihak sekolah, pembina, siswa, alat pendukung atau sarana-prasarana, serta orang tua siswa.Pelaksanaan kegiatan Pramuka di SD Negeri 004 Samarinda Utara didukung oleh banyak hal, salah satunya oleh pihak sekolah. Demi kelancaran kegiatan Pramuka di SD Negeri 004 Samarinda Utara ini pihak sekolah menyediakan sarana dan prasarana yang diperlukan. Kepala Sekolah mengatakan bahwa:

"sekolah sudah pasti menyediakan sarana prasarana guna untuk mendukung kegiatan Pramuka, karena tanpa sarana prasarana kegiatan Pramuka tidak dapat berjalan dengan semestinya" (hasil wawancara pada 15 November 2019).

Hal ini dibenarkan oleh pembina pramuka yang juga mengungkapkan bahwa:"pihak sekolah telah menyediakan sarana prasarana yang diperlukan dalam kegiatan Pramuka, hal ini dengan harapan untuk mendukung kegiatan tersebut berjalan maksimal sesuai rencana". Lebih lanjut untuk mengetahui apa saja sarana prasarana yang telah disediakan oleh sekolah guna mendukung optimalisasai kegiatan Pramuka Kepala Sekolah menyampaikan sebagai berikut;

“...pihak sekolah menyediakan juga mneyediakan perlengkapan kemah seperti tenda, bendera, tongkat dan tali-temali." (hasil wawancara pada 15 November 2019.)

Keterangan di atas juga dibenarkan oleh pembina pramuka yang menerangkan bahwa pihak sekolah telah menyediakan sarana prasarana penunjang kegiatan Pramuka di SD Negeri 004 Samarinda Utara. Pembina pramuka menambahkan bahwa:

"...pihak sekolah juga menyediakan tenda berkemah, bendera regu dan bendera lain yang dibutuhkan dalam kegiatan pramuka, selain itu juga pihak sekolah melengkapi kebutuhan PPPK" (hasil wawancara pada 15 November 2019).

Keterangan di atas menunjukkan bahwa ada dukungan penuh dari pihak sekolah guna menyelenggarakan kegiatan secara maksimal sesuai dengan rencana yang telah dibuat.Sarana prasarana yang telah disediakan juga dimanfaatkan secara maksimal dalam kegiatan pramuka. Sarana prasarana yang telah disediakan tersebut sudah dimanfaatkan dengan baik dalam kegiatan Pramuka. Jika pelatihan yang berlangsung materinya membutuhkan alat, maka siswa diminta menggunakan alat-alat yang telah tersedia.

Seluruh sarana prasarana yang disediakan tersebut seluruhnya ditanggung oleh pihak sekolah. Pihak sekolah mendapatkan dana untuk pelaksanaan kegiatan Pramuka seluruhnya dari bantuan dana BOS (Bantuan Operasional Sekolah). Jadi pihak sekolah sama sekali tidak memberi beban pendanaan kepada peserta maupun orang tua siswa yang mengikuti Pramuka tersebut.

Pernyataan tersebut dibenarkan oleh salah satu siswa yang mengikuti kegiatan Pramuka di SD Negeri 004 Samarinda Utara, dalam wawancara siswa menjelaskan sebagai berikut:

"...sama sekali orang tua tidak diberi beban dalam hal pendanaan dalam kegiatan Pramuka yang diikuti oleh anak, paling hanya membeli pakaian pramuka lengkap dengan atributnya" (hasil wawancara pada 20 November 2019).

Selain bantuan pendanaan, salah satu faktor pendukung terlaksananya kegiatan pramuka adalah adanya dukungan positif dari orang tua siswa.Adanya dukungan orang tua dapat membantu dan memotivasi anak dalam mengikuti setiap kegiatan pramuka yang dilaksanakan di SD Negeri 004 Samarinda Utara. Selain itu dukungan orang tua juga memiliki harapan tersendiri dengan ikutnya anaknya dalam kegiatan Pramuka akan terjadi pembentukan sikap dan watak yang lebih baik pada anak. Dengan kegiatan Pramuka tersebut dapat meningkatkan kedisiplinan siswa dan anak menjadi mandiri dan terampil serta bertanggungjawab.

Hal tersebut menjelaskan bahwa dengan mengikuti Pramuka, orang tua berharap agar anakanaknya dapat mengembangkan kepribadian dan karakter yang lebih baik dan diharapkan kegiatan tersebut dapat mempengaruhi sikap siswa dalam pembelajaran di kelas maupun dalam kehidupan sehari-hari di masyarakat.Selain itu penyampaian materi dan metode kegiatan juga menjadi salah satu faktor pendukung pelaksanaan kegiatan Pramuka ini.

Metode Kepramukaan perlu dilakukan secara menyenangkan dan terarah agar berjalan sesuai dengan manfaat pramuka itu sendiri yaitu sebagai kegiatan yang menarik bagi anak siswa.Kegiatan menarik di sini dimaksudkan yaitu kegiatan yang menyenangkan dan mengandung unsur pendidikan.Karena itu permainan harus mempunyai tujuan dan aturan permainan, jadi bukan sekadar main-main ataupun yang hanya 
bersifat hiburan saja, tanpa aturan dan tujuan dan tidak bernilai pendidikan.

Dalam pelaksanaan kegiatan pramuka di SD Negeri 004 Samarinda Utara, baik kepala sekolah maupun pembina pramuka menerapkan materi dan

kegiatan yang berpedoman pada buku saku pramuka. Meskipun demikian tidak semua kegiatan dapat sesuai dengan harapan.Oleh karena itu, agar kegiatan pramuka di minggu berikutnya berjalan dengan baik dan tidak terjadi kekurangan maka setiap selesai kegiatan Kepala Sekolah bersama pembina pramuka melakukan evaluasi kegiatan.Pembina pramuka menjelaskan bahwa guna memaksimalkan kegiatan di setiap minggunya selalu ada evaluasi kegiatan Pramuka. Yang di evaluasi terdiri dari pelatihan yang berlangsung, sikap siswa, dan sikap pembina dalam mengajar (hasil wawancara pada 15 November 2019).

Selain evaluasi mingguan, pihak sekolah juga mengadakan evaluasi di setiap semester dan tahunnya. Hal ini seperti yang diungkapkan ibu Kepala Sekolah bahwa demi pelaksanaan Pramuka berlangsung sesuai dengan tujuan pramuka, sekolah setiap tahunnya mengadakan evaluasi.Beberapa segi yang di evaluasi adalah pelatihan setiap minggu yang dilaksanakan dan perkembangan sikap dilihat dari nilai setiap semesternya (hasil wawancara pada 15 November 2019).

Dari keterangan diatas dapat diketahui bahwa setiap kegiatan Pramuka di SD Negeri 004 Samarinda Utara dilakukan evaluasi.Hal ini bertujuan agar kegiatan yang dilaksanakan berjalan sesuai dengan tujuan pembelajaran.Keberlanjutan kegiatan Pramuka seperti evaluasi ini juga menjadi faktor penting kelancaran kegiatan Pramuka di SD Negeri 004 Samarinda Utara, Tetapi kenyataan pelaksanaanPramuka disetiap pertemuan dalam latihan rutin baik pembina maupun Kepala Sekolah tidak terlihat melakukan evaluasi disetiap latihan rutinya. Padahal itu merupakan faktor penting demi tercapainya tujuan kegiatan Pramuka yang salah satu susunan progam sekolah, agar pihak sekolah maupun pembina mengetahui pekembangan siswa juga perkembangan pelaksanaan kegiatan Pramuka

Terlaksananya kegiatan pramuka dengan baik di SD Negeri 004 Samarinda Utara dipengaruhi oleh berbagai faktor, diantaranya adalah dari dukungan pihak sekolah yang berupa bantuan sarana prasarana. Dukungan pemerintah yaitu adanya dana Bantuan Operasional Sekolah (BOS) yang dapat digunakan untuk mendanai kegiatan pramuka tanpa harus memungut biaya dari siswa maupun dari orang tua siswa, dukungan pembina pramuka yang senantiasa mengembangkan metode dan pengajaran yang menyenangkan agar materi materi dapat sampai ke siswa dengan menyenangkan pula bagi siswa, dan dukungan dari orang tua siswa yang senantiasa mendorong dan memotivasi siswa untuk selalu aktif dalam kegiatan pramuka.

Berdasarkan uraian di atas maka dapat diketahui bahwa faktor pendukung pelaksanaan kegiatan Pramuka di SD Negeri 004 Samarinda Utara antara lain: adanya sarana prasarana yang disediakan sekolah, adanya dana BOS yang mendukung pendanaan kegiatan Pramuka, dukungan orang tua, dan pembina memberikan metode pengajaran sesuai dengan Metode Kepramukaan .

\section{Hambatan dalam Pelaksanaan Kegiatan Pramuka \\ Dalam setiap kegiatan yang terjadi di} sebuah instansi tentu menemui hambatanhambatan dan gangguan yang menyebabkan kegiatan tersebut tidak berjalan maksimal. Begitu juga yang terjadi dalam kegiatan Pramuka di SD Negeri 004 Samarinda Utara. Meskipun terbilang lancar dalam pelaksanaannya namun tetap saja masih terdapat kekurangan kekurangan yang menyebabkan tidak maksimalnya kegiatan yang berlangsung.

Dalam beberapa pertemuaan, pembina pramuka tampak kesulitan mengelola siswa.Hal ini terlihat misalnya pada saat menyambung dua tongkat banyak siswa yang asik bermain sendiri, hanya sebagian siswa atau hanya ketua regu saja yang berlatih menyambung tongkat.

Tingkat ketertiban siswa saat menyambung dua tongkat, dengan banyaknya siswa yang mengikuti yang berjumlah sekitar 100 siswa dan terbagi menjadi $11 \mathrm{regu}$, pembina hanya 2 , dari masing-masing regu, berkumpulnya jaraknya berdekatan, sehingga menimbulkan kegaduhan dan kurangnya ketertiban siswa, sehingga siswa tidak berkosentrasi untuk regunya sendiri, kadang bermain dengan regu yang lain. Hal ini juga tidak terlepas dari kurangnya pembina pramuka, sehingga pembina pramuka tampak sedikit kesulitandalam mengondisikan semuasiswa.

Hasil observasi yang dilakukan peneliti selama proses penelitian yang terjadi selama 
kurang lebih dua bulan di SD Negeri 004 Samarinda Utara terdapat beberapa hambatan yang terjadi selama proses kegiatan Pramuka berlangsung. Hambatan terjadi terutama pada saat pelaksaan latihan rutin mingguan yang dilaksanakan setiap sabtu sore di lapangan SD Negeri 004 Samarinda Utara.

Pada observasi latihan rutin nampak kekurangan yang terjadi yaitu dalam setiap pertemuan dalam latihan rutin pembina pramuka belum nampak melakukan penilaian terhadap siswa dan baik pembina maupun Kepala Sekolah tidak terlihat melakukan evaluasi disetiap latihan rutinya.Padahal itu merupakan faktor penting demi tercapainya tujuan Pramuka yang salah satu susunan progam sekolah agar pihak sekolah maupun pembina mengetahui pekembangan siswa juga perkembangan pelaksanaan Pramuka.

Selanjutnya molornya waktu latihan dari yang dijadwalkan. Latihan yang harusnya dimulai pukul 15.00 harus mundur beberapa menit karena peserta kegiatan datang terlambat.Namun hal ini tidak mengurangi antusias siswa dalam mengikuti kegiatan. Akibat ketidaktepatan waktu ini durasi latihan jadi berkurang, yang seharusnya latihan selama 2 jam hanya menjadi 1 jam lebih beberapa menit saja. Selain itu, dalam pelaksanaan kegiatan rutin setiap minggunya sebagian siswa masih terdapat ketidakseriusan dan disiplin siswa dalam mengikuti kegiatan.Hal ini menyebabkan kegiatan Pramuka menjadi tidak kondusif.Selain itu jumlah siswa yang tidak seimbang dengan jumlah pembina juga menjadi salah satu hambatan jalannya kegiatan Pramuka di SD Negeri 004 Samarinda Utara.Seorang pembina yang dibantu satu orang pembantu pembina pramuka mengajarkan kepada kurang lebih 100 peserta atau siswa. Hal ini tentunya sangat kurang kondusif dalam pelaksanaan kegitan Pramuka. Hal ini dikarenakan dua orang pembina saja akan sangat sulit mengkondisikan 100 siswa dalam kegiatan. Hambatan tersebut tidak dirasakan sebagai sebuah hambatan besar yang dapat mengganggu jalannya kegiatan Pramuka. Baik Kepala Sekolah maupun pembina pramuka mengungkapkan bahwa tidak ada hambatan yang berarti dalam pelaksanaan kegiatan Pramuka di SD Negeri 004 Samarinda Utara.

Dari uraian di atas menunjukkan bahwa hambatan dalam pelaksanaan kegiatan Pramuka di SD Negeri 004 Samarinda Utaraantara lain: pembina pramuka kesulitan dalam mengelola kelas, terbatasnya jumlah pembina pramuka yang tidak sebanding dengan jumlah siswa, progam yang sudah disusun pihak sekolah tidak berjalan semestinya, dan disiplin siswa dalam mengikuti kegiatan pramukamasih kurang seperti banyaknya siswa yang terlambat dan tidak hadir dalam kegiatan pramuka.

\section{Pembahasan}

Hasil penelitian menunjukkan bahwa pelaksanaan kegiatan pramuka di SD Negeri 004 Samarinnda Utara pada awalnya disusun rencana program terstruktur di setiap semester maupun tahunan serta menyesuaikan dengan buku saku panduan pramuka.namun kenyataan pada saat pelaksanaan kegiatan pramuka berlangsung belum sesuai dengan progam sekolah.

Kegiatan pramuka untuk program latihan rutin dilaksanakan setiap hari sabtu pukul 15.0017.00 dan dilaksanakan di halaman SD Negeri 004 Samarinda Utara.Program lainnya dalam kegiatan pramuka ini seperti semaphore, kemah, baris bebaris, persami dan jelajah.Metode yang digunakan guru dalam mengajar sudah menggunakan Metode Kepramukaan.Namun kenyataan pada pelaksanaan pramuka tidak semua kegiatan dilakukan seperti kegiatan pengembaraan, penjelajahan dengan tanda jejak, ketangkasan pionering, dan keterampilan membaca sandi, sedangkan kegiatan yang dilakukan di SD Negeri 004 Samarinda Utara hanyalah kegiatan baris bebaris, tepuk tangan , dan semaphore.

Sejalan dengan pendapat Baden Powell (Boyman,2013: 3) yang mengatakan bahwa kepramukaan adalah suatu permainan yang mengandung pendidikan, seperti membuat tandu, mencari jejak, semaphore, jelajah dan berkemah. Hal ini juga sesuai dengan pendapat dalam buku kwartir nasional (2011:31) bahwa Metode Kepramukaan merupakan cara belajar progesif melalui: (a) pengamalan Kode Kehormatan Pramuka; (b) belajar sambil melakukan; (c) sistem berkelompok/beregu; (d) kegiatan yang menarik di alam terbuka yang mengandung pendidikan yang sesuai dengan perkembangan rohani dan jasmani anggota muda; (e) kegiatan di alam terbuka; (f) kemitraan dengan anggota dewasa dalam setiap kegiatan; (g) sistem tanda kecakapan; (h) sistem satuan terpisah untuk putera dan putri; (i) kiasan dasar.

Perencanaan kegiatan Pramuka di SD Negeri 004 Samarinda Utara telah dipersiapkan dengan matang.Hal ini terlihat dengan adanya 
program semester dan tahunan untuk kegiatan Pramuka di SD Negeri 004 Samarinda Utara.Dalam perencanaannya pihak sekolah maupun pembina pramuka menggunakan buku saku panduan pramuka sebagai pedoman kegiatan dalam pelaksanaan Pramuka.

Hal ini dilakukan agar pelaksanaan kegiatan Pramuka tetap berlandaskan pada asasasas pramuka dan tidak melenceng dari tujuan pramuka itu sendiri, sama seperti yang ada pada Kwartir Nasional Gerakan Pramuka (2011:43), yang menyatakan program kegiatan merupakan faktor yang sangat penting bagi suatu perkumpulanorganisasi dalam upaya mencapai tujuan bersama dengan cara yang efektif dan efisien. Namun kenyataan saat pelaksanaan kegiatan pramuka berlangsung belum sesuai dengan progam perencanaan yang sudah disusun sekolah dikarenakan berbagai aspek.Selain menyiapkan program kegiatan, pihak sekolah juga menyiapkan anggaran dan sarana-prasarana guna mendukung terlaksananya kegiatan pramuka secara maksimal. Namun kenyataan pada saat observasi peneliti hanya melihat sebagian saja yang sekolah melengkapi sarana prasaran seperti, tongkat, tali, tenda, sedangkan peralatan seperti Pertolongan Pertama Pada Kecelakaan (PPPK).

Kegiatan Pramuka ini diharapkan mampu membentuk karakter dan watak yang baik bagi siswa. Hal tersebut sependapat dengan baden powell (boyman,2013: 03) bahwa kepramukaan adalah suatu permainan yang menyenangkan di alam terbuka, tempat orang dewasa dan anak-anak pergi bersama-sama, mengadakan pengembaraan bagaikan kakak beradi, membina kesehatan dan kebahagian, keterampilan dan kesediaan untuk memberi pertolongan bagi yang membutuhkannya.

Hal ini juga sejalan denganpendapat Hasan Lamggulung (2006: 182) bahwa manfaat ektrakurikuler yaitu untuk mengembangkan potensi-potensi yang ada pada diri individuagar dapat dipergunakan oleh dirinya dan masyarakat untuk menghadapi tantangan-tantangan yang selalu berubah. Faktor-faktor pendukung dalam kegiatan kepramukaan ialah adanya progam yang disusun oleh pihak sekolah. Dalam latihan rutin pembina pramuka juga menggunakan Prinsip Dasar Kepramukaan serta Metode Kepramukaan. Pihak sekolah juga menyediakan prasarana guna mengoptimalkan kegiatan Pramuka diantaranya adalah tenda, bendera, tali temali, tongkat dan peralatan PPPK, selain itu pihak sekolah juga menyediakan dana guna untuk keperluan agenda akhir semester atau tahunnya dalam kegiatan Pramuka yang diambil dari dana BOS (Bantuan Operasional Sekolah). Siswa ataupun orang tua sama sekali tidak dikenakan biaya apapun dalam kegiatan Pramuka.

Dukungan orang tua siswa juga memberikan pengaruh besar terhadap terlaksananya kegiatan Pramuka di SD Negeri 023 Samarinda Utara. Dengan adanya dukungan yang besar terhadap siswa makan akan tercipta motivasi yang tinggi pada anak untuk aktif mengikuti kegiatan Pramuka.Hal di atas merupakan faktorfaktor pendukung pelaksanaan kegiatan Pramuka yang sesuai dengan buku Kwartir Nasional Gerakan Pramuka (2011:43), yang menyebutkan faktor-faktor penting dalam kepramukaan ialah peserta didik, pembina, program, Prinsip Dasar Kepramukaan, Metode Kepramukaan , sarana prasarana dan alam terbuka serta masyarakat.

Berkaitan dengan rangka mendukung kelancaran kegiatan Pramuka di SD Negeri 004 SamarindaUtara. Sebenarnya pihak sekolah, Kepala Sekolah bersama dengan pembina pramuka mempunyai rencana program evaluasi disetiap minggu dan tahun.Dalam evaluasi rutin mingguan mengenai pelaksanaan pelatihan yang berlangsung, bagaimana sikap siswa selama mengikuti pelatihandan bagaimana sikap pembina saat melakukan kegiatan. Evaluasi tahunan dilakukan guna menyempurnakan kegiatan yang akan dilaksanakan di tahun berikutnya. Akan tetapi pihak sekolah maupun pembina pramuka, dalam observasi peneliti belum melaksanakan evaluasi yang sesuai rencana progam yang diharapkan dari sekolah.

Pelaksanaan Pramuka di SD Negeri 004 Samarinda Utara tidak serta merta berjalan lancar sesuai rencana, dalam pelaksanaannya pasti adakendala dan hambatan yang membuat pelaksanaan tidak berjalan maksimal.Hal ini sebagaimana hasil observasi yang dilakukan peneliti menunjukkan dalam pelaksanaan kegiatan Pramuka tersebut pembina belum mengacu pada program yang dibuat sekolah.

Hal itu terlihat dalam setiap pertemuan dalam latihan rutin pembina maupun pembantu pembina pramuka belum sesuai rencana progam sekolah dalam pelatihannya, nampak penilaian terhadap siswa belum terlihat, dan pembina maupun Kepala Sekolah tidak terlihat melakukan evaluasi disetiap latihan rutinya. Padahal itu merupakan salah satu susunan progam sekolah 
agar pihak sekolah maupun pembina mengetahui pekembangan siswa juga perkembangan pelaksanaan kegiatan pramuka. Jadi progam yang sudah disusun pihak sekolah tidak berjalan dengan apa yang semestinya dalam pelaksanaan kegiatan pramuka.

Padahal dalam buku Kwartir Nasional Gerakan Pramuka (2011:43), yang menyatakan program kegiatan merupakan keseluruhan dari apa yang dilakukan peserta kepramukaan dan bagaimana aktivitas itu dilaksanakan serta alasan mengapa aktivitas itu dilaksanakan. Selanjutnya bahwa siswa kurang disiplin dalam mengikuti kegiatan Pramuka. Hal ini terlihat tingkat keberangkatan siswa dan saat diberi tugas oleh pembina pramuka.

Dari molornya jadwal pelaksanaan kegiatan yang seharusnya dilaksanakan setiap jumat pukul 15.00-17.00 tetapi kegiatan sering dilaksanakan terlambat itu merupakan suatu masalah. Hal ini menyebabkan kurang maksimalnya waktu latihan yang sebelumnya dijadwalkan latihan selama 2 jam harus berkurang menjadi kurang dari dua jam. Selain itu, dalam setiap pertemuan dalam latihan rutin selalu ada siswa yang tidak hadir dalam kegiatan pramuka. Bahkan dari hasil observasi yang dilakukan peneliti mencapai 15 siswa yang tidak hadir dalam kegiatan pramuka.

Hal di atas menunjukan adanya perbedaan yang dinyatakan Joko Mursitho (2010: 11), bahwa kepramukaan merupakan proses pendidikan yang menciptakan pembentukan watak, diantaranya kedisiplinan. Hambatan yang terjadi pada pelaksanaan kegiatan pramuka di SD Negeri 004 Samarinda Utara ini juga menunjukkan bahwa ada tujuan pramuka yang tidak tercapai dalam pelaksanaannya.

Menurut Irfan Ali Nasruddin (2018: 20) salah satu tujuan kegiatan pramuka yaitu memiliki kepribadian yang beriman, bertakwa, berakhlah mulia, berjiwa patriontik, taat hukum, disiplin, berkecakapan hidup, sehat jasmani dan rohani.Namun yang terjadi pada pelaksanaan pramuka adalah masih adanya siswa yang kurang meminati program sekolah dalam hal ini kegiatan pramuka. Hal ini nampak dari banyaknya siswa yang terlambat datang dan tidak fokus dalam mengikuti kegiatan.Mengatasi hal ini harusnya pihak sekolah baik Kepala Sekolah maupun pembina pramuka memperbarui program sekolah khususnya kegiatan Pramuka agar lebih menarik dan diminati siswa.
Hambatan juga datang dari ketidakseimbangan jumlah pembina dengan jumlah peserta atau siswa yang mengikuti kegiatan Pramuka.Di SD Negeri 004 Samarinda Utara hanya mempunyai terdapat dua pembina pramuka.Jumlah pembina ini sangat kurang jika dibandingkan dengan jumlah siswa peserta Pramuka dari kelas IV dan V yang berjumlah lebih dari 100 siswa.

Padahal rasio pembina dengan peserta didik menurut Kh. Ahmad Dahlan Dan Nyi Hj. Ahmad Dahlan (2008:32), diantaranya: (a)Satu Perindukan Siaga beranggotakan maksimal 40 Siaga dikelola oleh sorang Pembina dibantu oleh 3 orang Pembantu Pembina; (b)Satu Pasukan Pengalang beranggotakan maksimal 40 Penggalang dikelola oleh seorang Pembina dibantu oleh 2 Pembantu Pembina.

Minimnya tenaga pembina pramuka ini membuat jalannya kegiatan kurang maksimal, karena dua orang pembina saja tidak dapat mengkondisikan 100 siswa peserta kegiatan Pramuka.Hal ini membuat kegiatan latihan kurang kondusif dan siswa kurang disiplin dalam mengikuti kegiatan karena sibuk main sendiri atau mengobrol sendiri dengan temannya yang lain.

Dengan demikian dapat disimpulkan bahwa pelaksanaan kegiatan pramuka di SD Negeri 004 Samarinda Utara belum sesuai berjalan secara maksimal.kegiatan pramuka ini telah dilaksanakan sesuai dengan prinsip dasar pramuka seperti yang diungkapkan Dimas Rahmat (2010: 10), yaitu kepramukaan pada hakekatnya adalah suatu proses pendidikan dalam bentuk kegiatan yang menyenangkan bagi anak dan pemuda di bawah tanggung jawab orang dewasa yang dilaksanakan di luar lingkungan pendidikan sekolah dan di luar lingkungan pendidikan keluarga dan di alam terbuka dengan menggunakan prinsip dasar dan Metode Kepramukaan.

Meskipun demikian kegiatan Kepramukaan di SD Negeri 004 Samarinda Utara masih belum berjalan maksimal. Oleh karena itu, perlu kerjasama dengan berbagai pihakdalam mengoptimalkan kegiatan pramuka baik dari pihak sekolah, siswa maupun orang tua siswa secara intensif.

\section{KESIMPULAN}

Berdasarkan deskripsi hasil penelitian dan pembahasan, maka dapat ditarik tiga kesimpulan bahwa Pelaksanaan kegiatan Pramuka di SD Negeri 004 Samarinda Utara,sekolah telah 
menyusun rencana program yang berpedoman pada buku SKU pramuka.SD Negeri 004 Samarinda Utara memiliki kegiatan tahunan dan kegiatan mingguan yang menjadi agenda rutin. Dalam mengajar, pembina pramuka telah menggunakan Metode Kepramukaan. Kegiatan Pramuka ini diharapkan mampu membentuk karakter dan watak pada siswa. Terlakasananya kegiatan pramuka ini juga dipengaruhi oleh beberapa faktor, diantaranya mempunyai program tersruktur, menyediakan sarana prasarana, dukungan orang tua, dan sekolah juga menyediakan dana yang berasal dari Bantuan Operasional Sekolah (BOS).

\section{DAFTAR PUSTAKA}

Afrizal, (2016). Metode Penelitian Kualitatif (cetakan ke III). Jakarta : Raja Grafindo Persada.

Angrini, Dina (2017) kegiatan Ekstrakurikuler Pramuka Dalam Menerapkan Karakter Tanggung JawabDi SD Negeri NO.64/I Muara Buliantahun pembelajaran $2016 / 2017$.

Depdikbud. (1985). Buku Petunjuk Pelaksaan Proses Belajar Mengajar. Jakarta: Depdikbud.

Elfachmi, (2016). Pengantar Pendidikan. Erlangga.

Ernawati, Erni (2018).Analisis Pelaksanaan Kegiatan Ekstrakurikuler Kepramukaan Di SDN 55/I Sridadi Tahun Pembelajaran $2017 / 2018$
Jayanti. Buku Lengap Pramuka.Media Ilmu Abadi.

Joko Utomo, (2014), Pelaksanaan Extrakulikuler pramukadi $S D$ Wates. yogyakarta

Kh. Ahmad Dahlan dan Nyi Hj. Ahmad Dahlan. (2008), Kursus Pembina Pramuka Mahir Tingkat Dasar 2008. Purwokerto:Lemdika Gerakan Pramuka.

Kwartir Nasional Gerakan Pramuka. (2011). Kursus Pembina Pramuka Mahir Tingkat dasar. Jakarta: Kwartir Nasional Gerakan Pramuka

Nasruddin (2018). Buku Komplit Pramuka (cetakan Pertama). Yogyakarta: CV. Briliant.

Peraturan Menterti Pendidikan dan Kebudayaan Republik Indonesia No 63 Tahun 2014 tentang pendidikan kepramukaan.

Sugiyono, (2015). Metode Penelitian Pendidikan (cetakan ke- 21). Bandung: Alfabeta.

Sunardi, (2013). Boyman Ragam Latih Pramuka ( cetakan ke VIII). Bandung: Nuansa Muda.

Sugiyono, (2018). Metode Penelitian Pendidikan (cetakan ke- 27). Bandung: Alfabeta

Sugiyono. (2013). Metode Penelitian Kuantitatif Kualitatif dan R\&D. Bandung: Alfabeta.

Team DAP. Buku Pintar Pramuka. Jakarta: DAP Jakarta.

Tim Editor KMD (2011). Kursus Pembina Pramuka Mahir Tingkat Dasar. Jakarta: Kwartir Nasional Gerakan Pramuka.

Undang Undang Republik Indonesia Nomor 12 Tahun 2010 tentang Gerakan Pramuka.

Undang-Undang RI Nomor 2 Tahun 2003, Tentang Sistem Pendidikan Nasional. 